\title{
AOR
}

Selected Papers of \#AoIR2019:

The $20^{\text {th }}$ Annual Conference of the Association of Internet Researchers Brisbane, Australia / 2-5 October 2019

\section{PUNCHING UP OR TURNING AWAY? WHEN PALESTINIANS UNFRIEND JEWS IN ISRAEL}

Nicholas John

Department of Communication and Journalism, The Hebrew University of Jerusalem, Israel

Aysha Agbarya

Department of Communication and Journalism, The Hebrew University of Jerusalem, Israel

In this paper we present findings from in-depth interviews with 20 Palestinian citizens of Israel who have unfriended Jewish Israelis on Facebook for reasons related to the Israel-Palestine conflict. In doing so, we introduce considerations of structural inequality to the literature on unfriending (Light \& Cassidy, 2014; Sibona \& Walczak, 2011).

Unfriending has been attracting growing attention, particularly with regard to disconnective behaviors surrounding the exposure to and consumption of political content and news on social media platforms. Survey-based studies carried out in the US (Bode, 2016), Colombia (Yang, Barnidge, \& Rojas, 2017), Germany (Gashi \& Knautz, 2016), Israel (John \& Dvir-Gvirsman, 2015), and Hong Kong (Zhu, Skoric, \& Shen, 2016) present a fairly clear picture: politically-motivated unfriending tends to be carried out by more politically active users positioned towards the extremes of the political spectrum. These findings are largely presented within a framework of selective exposure and the formation of filter bubbles, where there is an implicit assumption that unfriending should be understood as a proxy for intolerance.

Interview-based studies (Asmolov, 2018; John \& Gal, 2018; Lopez \& Ovaska, 2013) allow for more nuanced explications of interviewees' actions. From them we learn that unfriending is a complex mixture of content avoidance (akin to changing TV channels) and communication (letting someone know, albeit indirectly, that their views are unacceptable). 
However, none of these studies engages significantly with the possibility that unfriending might be fraught with power relations. Relatedly, studies of unfriending in the Israeli context have included only Jewish Israelis in their research populations. This study redresses this imbalance--indeed, it offers the first study of the unfriending of members of a majority group by members of a minority group. This adds complexity to our understanding of unfriending, while also shedding light on the experience of social media use from the perspective of an oppressed and heavily surveilled minority (Zureik, Lyon, \& Abu-Laban, 2010).

Accordingly, twenty '48 Palestinians (Palestinians who live within the 1948 borders of Israel and who have Israeli citizenship) who had unfriended a Jewish Israeli were interviewed by one of the authors, a religious Muslim woman and a member of that population. Participants were asked about their experiences of unfriending Jewish Israelis: What led up to the unfriending? How did they feel afterwards? Did they talk about it, either with the person they had unfriended, or with anyone else? The interviewees, who were comprised of an equal number of men and women, were aged between 21 and 37 . They were mostly traditional or religious, though some were secular. The in-depth semi-structured interviews were recorded and transcribed, and submitted to thematic analysis, based on a series of readings and re-readings of the transcripts.

Nearly all of the interviewees reported unfriending a Jewish Israeli against a background of racist hate speech. Usually, this speech was directed against Arabs in general, and not personally at the interviewees themselves. However, some interviewees were deeply and personally offended, not only because Jewish Facebook friends had posted racist content, but because they had done so in their (Facebook-mediated) presence.

Most of the accounts of unfriending fell within two broad categories. In the first, interviewees unfriended Jewish Israelis as a way of expressing their agency in the face of racist posts. For these interviewees, unfriending is somewhat akin to giving someone the finger (albeit without them necessarily seeing that). We refer to this as punching up. While the limitations of a non-representative sample must be borne in mind, we note that this approach was more common among more politically active interviewees. They also reported more positive feelings about the act of unfriending (e.g. relief) and active feelings about the behavior that caused the unfriending (especially anger).

In the second category, interviewees unfriended Jewish Israelis as an avoidance strategy. This might be in order to avoid surveillance by Jewish Israelis, thereby affording them greater freedom of expression, or it might be in order to avoid hate speech. We see this as a kind of turning away, or withdrawal from interaction. These interviewees tended to be less politically-minded, and expressed more negative and passive feelings (such as disappointment in their Jewish Facebook friends, or fear). They were especially aware that posting anti-Israeli content could land them in trouble with their employers or at college/university.

While participation in a deliberative democracy requires exposure to a range of opinions and views, this does not extend to hate speech. While unfriending ties because of 
cross-cutting political views may help to construct filter bubbles, unfriending ties because of hate speech could be seen as an appropriate response towards the creation of a safe online space. For our interviewees, what makes Facebook safer is having fewer Jewish Israeli friends, who may post racist speech, or who may even more actively seek out "disloyal" citizens and seek to have them punished.

Where dyadic pairs on Facebook enjoy more or less equal social standing, then there may be something to Facebook's belief that connecting people across the world can improve cross-cultural understanding. However, when one social group enjoys power over another, it would seem that the positive potential of online ties is limited.

Regardless of how empowered they felt by unfriending a Facebook tie from a more powerful social group, our interviewees felt safer having done so. Indeed, noting that unfriending was largely a response to an action by Jewish Israeli Facebook users; that the interviewees did not talk to the people they unfriended about their hate speech; and that in many instances they unfriended people with whom they were no longer in faceto-face contact, all points to a feeling of a lack of power relative to Jewish Israeli users.

Further research should explore unfriending in other contexts of inequality. This may be based on ethnicity, gender, class, sexuality, or some other dimension. Particular attention should be paid to the use of unfriending as a tool of agency and empowerment that creates a sphere for greater freedom of expression.

\section{References}

Asmolov, G. (2018). The Disconnective Power of Disinformation Campaigns. Journal of International Affairs, 71(1.5), 69-76.

Bode, L. (2016). Pruning the news feed: Unfriending and unfollowing political content on social media. Research \& Politics, 3(3). doi:10.1177/2053168016661873

Gashi, L., \& Knautz, K. (2016). Unfriending and becoming unfriended on Facebook. In K. Knautz \& S. Baran Katsiaryna (Eds.), Facets of Facebook, Use and Users (pp. 1-44). Berlin: de Gruyter GmbH.

John, N. A., \& Dvir-Gvirsman, S. (2015). 'I don't Like you any more’: Facebook unfriending by Israelis during the Israel-Gaza conflict of 2014. Journal of Communication, 65(6), 953-974. doi:10.1111/jcom.12188 
John, N. A., \& Gal, N. (2018). "He's Got His Own Sea": Political Facebook Unfriending in the Personal Public Sphere. International Journal of Communication, 12, 18.

Light, B., \& Cassidy, E. (2014). Strategies for the suspension and prevention of connection: Rendering disconnection as socioeconomic lubricant with Facebook. New Media \& Society, 16(7), 1169-1184. doi:10.1177/1461444814544002

Lopez, M. G., \& Ovaska, S. (2013). A look at unsociability on Facebook. Paper presented at the 27th International BCS Human Computer Interaction Conference.

Sibona, C., \& Walczak, S. (2011). Unfriending on Facebook: Friend request and online/offline behavior analysis. Paper presented at the System Sciences (HICSS), 2011 44th Hawaii International Conference on System Sciences.

Yang, J., Barnidge, M., \& Rojas, H. (2017). The politics of "Unfriending": User filtration in response to political disagreement on social media. Computers in Human Behavior, 70, 22-29. doi:http://dx.doi.org/10.1016/j.chb.2016.12.079

Zhu, Q., Skoric, M., \& Shen, F. (2016). I Shield Myself From Thee: Selective Avoidance on Social Media During Political Protests. Political Communication, 1-20. doi:10.1080/10584609.2016.1222471

Zureik, E., Lyon, D., \& Abu-Laban, Y. (2010). Surveillance and control in Israel/Palestine: Population, territory and power: Routledge. 